\title{
Pre-treatment of human mesenchymal stem cells with inflammatory factors or hypoxia does not influence migration to osteoarthritic cartilage and synovium
}


Pre-treatment of human mesenchymal stem cells with inflammatory factors or hypoxia does not influence migration to osteoarthritic cartilage and synovium

Maarten J.C. Leijs, *y MD, Gerben M. van Buul,*MD, PhD, Jan A.N. Verhaar, *MD, PhD, Martin J. Hoogduijn, PhD, Pieter K. Bos, ${ }^{*}$ MD, PhD, and Gerjo J.V.M. van Osch, *\$ $\|$ PhD Investigation performed at the Erasmus MC Rotterdam, the Netherlands

\begin{abstract}
Background: Mesenchymal stem cells (MSCs) are promising candidates as a cell-based therapy for osteoarthritis (OA), although current results are modest. Pre-treatment of MSCs before application might improve their therapeutic efficacy.
\end{abstract}

Hypothesis: Pre-treatment of MSCs with inflammatory factors or hypoxia will improve their migration and adhesion capacities towards OA affected tissues.

Study Design: Controlled Laboratory Study; in vitro and in vivo.

Methods: We determined effects of different fetal calf serum (FCS) batches, platelet lysate (PL), hypoxia, inflammatory factors, factors secreted by OA tissues and OA synovial fluid (SF) on the expression of twelve genes encoding chemokine or adhesion receptors by RT-PCR. Migration of MSCs towards factors secreted by OA tissues was studied in vitro, and attachment of injected MSCs was evaluated in vivo in healthy and OA male Wistar rat knees.

Results: Different FCS batches, PL or hypoxia did not influence the expression of the migration and adhesion receptor genes. Exposure to inflammatory factors altered the expression of $C C R 1$, CCR4, CD44, PDGFR $\alpha$ and PDGFR $\beta$. MSCs migrated towards factors secreted by OA tissues 
in vitro. Neither pre-treatment with inflammatory factors nor the presence of OA influenced MSC migration in vitro or adhesion in vivo.

Conclusion: Factors secreted by OA tissues increase MSC migration in vitro. In vivo no difference in MSC adhesion was found between OA and healthy knees. Pre-treatment with inflammatory factors influenced the expression of migration and adhesion receptors of MSCs, but not their migration in vitro or adhesion in vivo.

Clinical Relevance: To improve the therapeutic capacity of intra-articular injection of MSCs, MSCs need to remain intra-articular for a longer period of time. Pre-treatment of MSCs with hypoxia or inflammatory factors did not increase their migration or adhesion capacity and will therefore not likely prolong their intra-articular longevity. Alternative approaches to prolong intra-articular presence of MSCs should be developed to increase the therapeutic effect of MSCs in OA.

Key Terms: Mesenchymal stem cells, migration, osteoarthritis, cell therapy, inflammation

\section{Introduction}

Osteoarthritis (OA) is characterized by an inflammatory and catabolic intra-articular environment, which causes progressive degeneration and inflammation of multiple intra-articular tissues. Sport-related injuries like anterior cruciate ligament ruptures or meniscal tears increase the incidence of OA. ${ }^{2,50}$ To date, only symptomatic treatments are available for OA. A successful strategy to cure OA would consist of long term modulation of the degenerative joint environment by simultaneously reducing inflammation and promoting tissue regeneration. Mesenchymal stem cells (MSCs) are promising candidates for this therapeutic approach of OA, 
They have been shown capable of suppressing immune-mediated cartilage destruction while contributing to cartilage repair via their chondrogenic differentiation and paracrine stimulation of endogenous repair processes. ${ }^{8,16,27,33}$ The use of MSCs as cell-therapy for OA by intra-articular injection has been reported to be safe. ${ }^{4,34}$ Clinical trials and pre-clinical studies did, however, not show consistent data on healing or regeneration of damaged tissues after MSC treatment. ${ }^{4,48} \mathrm{~A}$ possible explanation for these inconsistent results could be the fast decrease in number of viable MSCs after injection in the joint; No viable MSCs were detected in the joint one to two weeks after injection. ${ }^{44,46}$ A small proportion of intra-articularly injected MSCs attached to synovial surfaces after these injections, but almost none to the affected cartilage. ${ }^{32}$ During their rather short local intra-articular presence, MSCs can only have a small effect. In cardiology, it has been shown that providing a longer interplay between the diseased tissue and applied MSCs, increased the therapeutic effect. ${ }^{31,49,53}$ We hypothesized that pre-treatment of MSCs with inflammatory factors or hypoxia would improve their migration and adhesion capacities towards OA affected tissues.

The migration and adhesion of injected MSCs in OA joints will depend on multiple factors including the secreted chemotactic factors by OA joint tissues, the expression of chemotactic receptors for these factors and the expression of cell adhesion receptors by the MSCs. ${ }^{3}, 13,14,16,21$, 23, 24 In OA joints, the presence of multiple chemokines that can attract MSCs have been described. ${ }^{3,6}$ Furthermore, multiple chemokine receptors and adhesion receptors have already been indicated as possible migration receptors and adhesion receptors of MSCs. ${ }^{3}, 16,19,35,39,43,51$, ${ }^{54}$ Previous studies showed that the expression of these migration receptors can be influenced by exposure to inflammatory factors ${ }^{16,18,35,37}$ or hypoxia, ${ }^{10,22}$ but none of these studies evaluated the effect on intra-articular migration or adherence.. Moreover, exposure of MSCs to 
inflammatory factors increases their immunomodulatory capacities ${ }^{15,28,38,41}$ and was previously shown by us to increase the anti-inflammatory and anti-catabolic effects of MSCs on inflamed osteoarthritic joint tissues in culture. ${ }^{47}$ In this study we evaluated whether OA synovium and cartilage produce chemotactic factors that can stimulate MSCs to migrate and adhere to the OA affected tissues after injection and whether we could influence MSC migration capacities in vitro and adhesion capacities in vivo. 
TABLE 1

Abbreviations Used

\begin{tabular}{|c|c|}
\hline Abbreviation & Definition \\
\hline aMEM & $\begin{array}{l}\text { Minimum Essential Medium Eagle-alpha } \\
\text { modification }\end{array}$ \\
\hline CCR1 & C-C chemokine receptor type 1 \\
\hline CCR4 & C-C chemokine receptor type 4 \\
\hline CCR5 & C-C chemokine receptor type 5 \\
\hline cDNA & complementary DNA \\
\hline CM & conditioned medium \\
\hline CT & cycle threshold \\
\hline$C X C R 1$ & CXC chemokine receptor 1 \\
\hline CXCR3 & CXC chemokine receptor 3 \\
\hline CXCR4 & CXC chemokine receptor 4 \\
\hline CX3CL1 & fractalkine \\
\hline CX3CR 1 & $\begin{array}{l}\text { CX3C chemokine receptor } 1 / \text { fractalkine } \\
\text { receptor }\end{array}$ \\
\hline DMEM & Dulbecco's Modified Eagle’s Medium \\
\hline EDTA & ethylenediaminetetraacetic acid \\
\hline FCS & fetal calf serum \\
\hline FGF2 & fibroblast growth factor 2 \\
\hline GAG & glycosaminoglycan \\
\hline$H P R T$ & hypoxanthine phosphoribosyltransferase \\
\hline $\mathrm{IFN}-\gamma$ & interferon $\gamma$ \\
\hline IP-10 (CXCL10) & interferon $\gamma$-induced protein 10 \\
\hline IL-8 (CXCL8) & interleukin 8 \\
\hline ITG $\beta 1$ & integrin $\beta-1$ \\
\hline ITG $B 2$ & integrin $\beta-2$ \\
\hline ITS & insulin-transferrin-selenium \\
\hline MCP-1 (CCL2) & monocyte chemotactic protein 1 \\
\hline MCP-3 (CCL7) & monocyte chemotactic protein 3 \\
\hline MDC (CCL22) & macrophage-derived chemokine \\
\hline MIA & monoiodoacetate \\
\hline MIP-1a (CCL3) & macrophage inflammatory protein $1 \mathrm{a}$ \\
\hline MIP-1b (CCL4) & macrophage inflammatory protein $1 \mathrm{~b}$ \\
\hline MRI & magnetic resonance imaging \\
\hline mRNA & messenger RNA \\
\hline MSC & mesenchymal stem cell \\
\hline $\mathrm{OA}$ & osteoarthritis \\
\hline PBS & phosphate-buffered saline \\
\hline PDGF & platelet-derived growth factor \\
\hline PDGFR $\alpha$ & platelet-derived growth factor receptor $\alpha$ \\
\hline PDGFR $\beta$ & platelet-derived growth factor receptor $\beta$ \\
\hline PL & platelet lysate \\
\hline $\mathrm{SF}$ & synovial fluid \\
\hline SPIO & superparamagnetic iron oxide \\
\hline TNF- $\alpha$ & tumor necrosis factor $\alpha$ \\
\hline
\end{tabular}




\section{Methods}

Harvesting OA synovial fluid and conditioned medium of OA synovium and cartilage

Human synovial fluid (SF), cartilage explants and synovial explants were obtained as surgical waste material from patients undergoing total knee replacement surgery for OA. All patients implicitly consented to the use of these tissues for scientific research (with approval of medical ethical committee, MEC-2004-322).

To remove debris, SF samples were centrifuged (1600 rpm, $5 \mathrm{~min}$ ) and supernatant was subsequently stored at $-80^{\circ} \mathrm{C}$. Full thickness layers of uncalcified cartilage of macroscopically unaffected areas were taken from weight bearing and non-weight bearing parts of the tibial plateau and femur condyles. The synovial layerwas carefully dissected from Hoffa's fat pad, taking care to include as little fat tissue as technically possible. The cartilage and synovium explants were cut in 1-2 x 1-2 mm pieces. To generate conditioned medium (CM), $1 \mathrm{~g}$ of tissue was cultured per $5 \mathrm{ml}$ for $24 \mathrm{~h}$ in medium we used before ${ }^{5}$ consisting of Dulbecco's Modified Eagle Medium (DMEM) low glucose (Invitrogen, Carlsbad, CA, USA) containing 1\% ITS (Insulin-Transferrin-Selenium; BD Bioscience, Bedford, MA, USA), $1.5 \mu \mathrm{g} / \mathrm{ml}$ fungizone (invitrogen, Carlsbad, CA, USA), $50 \mu \mathrm{g} / \mathrm{ml}$ gentamicin (Invitrogen, Carlsbad, CA, USA), and $0.1 \mathrm{mM}$ of L-ascorbic acid 2-phosphate (vitamin C) (Sigma, St. Louis, MO, USA). CM was harvested after $24 \mathrm{~h}$, centrifuged $(1200 \mathrm{rpm}, 8 \mathrm{~min})$ and the supernatant was stored at $-80^{\circ} \mathrm{C}$.

Chemokine detection in OA synovial fluid and conditioned media of OA tissues 
Selected chemokines in SF of OA patients ( $\mathrm{n}=6$ patients, 2 male/4 female, 65.5 (59-73) years old), OA synovium CM ( $\mathrm{n}=6$ patients, 1 male/5 female, 63.3 (59-73) years old) and OA cartilage $\mathrm{CM}$ ( $\mathrm{n}=6$ patients, 2 male/4 female, 62.7 (54-70) years old) were measured by using a custom made 10-plex MILLIPLEX ${ }^{\circledR}$ multiplex assay (Merck Millipore, Temecula, CA, USA). Technical duplicates of the samples were used for the measurements. Ten factors were selected by matching known chemokine and adhesion receptors of MSCs with chemokines known to be present in in $\mathrm{OA} \mathrm{SF}^{3}, 6,18,23,35,39$ The multiplex assay was performed according to the manufacturer's protocol, with the human chemokine magnetic bead panel kit for Fractalkine (CX3CL1), Monocyte Chemotactic Protein 3 (MCP-3, CCL7), Macrophage-Derived Chemokine (MDC, CCL22), Platelet-Derived Growth Factor (PDGF)-AA, PDGF-BB, InterLeukin 8 (IL-8, CXCL8)), Interferon gamma-iduced Protein 10 (IP-10, CXCL10), Monocyte Chemotactic Protein 1 (MCP-1, CCL2)), Macrophage Inflammatory Protein-1a (MIP-1a, CCL3) and Macrophage Inflammatory Protein-1b (MIP-1b, CCL4) (EMD Millipore Corporation, Billerica, MA, USA). Assay read-out was performed by using Bio-Plex ${ }^{\circledR} 200$ multiplex array reader and Bio-Plex software (Bio-Rad Laboraties, Veenendaal, the Netherlands). Values below the minimum detectable concentration were set at $50 \%$ of the minimum detectable concentration.

Isolation and culture of MSCS

MSCs were isolated from heparinized femoral-shaft marrow aspirate of patients undergoing total hip arthroplasty, after signed informed consent and with approval of the local ethical committees. 5-10 $\mathrm{ml}$ marrow was harvested with sterile Jamshidi needles and sterile $10 \mathrm{ml}$ syringes 
containing $0.5 \mathrm{ml}$ of heparin $(1000 \mathrm{U} / \mathrm{ml}) \cdot 30-100 * 10^{6}$ mononuclear cells were plated in T175 flasks in $25 \mathrm{ml}$ expansion medium consisting of aMEM (Minimum Essential Medium Eagle Alpha Modification) (Invitrogen, Carlsbad, CA, USA) containing 10\% heat inactivated fetal calf serum (FCS) (Lonza, Verviers, Belgium, selected batch), $1.5 \mu \mathrm{g} / \mathrm{ml}$ fungizone, $50 \mu \mathrm{g} / \mathrm{ml}$ gentamicin, $1 \mathrm{ng} / \mathrm{ml}$ fibroblast growth factor-2 (FGF2) (Instruchemie B.V., Delfzijl, The Netherlands) and $0.1 \mathrm{mM}$ of vitamin C. After $24 \mathrm{~h}$, non-adherent cells and erythrocytes were removed by washing three times with $2 \%$ FCS in 1x PBS (invitrogen, Carlsbad, CA, USA). Remaining adherent cells were cultured in expansion medium at $37^{\circ} \mathrm{C}$ and $5 \%$ carbon dioxide $\left(\mathrm{CO}_{2}\right)$. Expansion media were renewed twice a week. Cells were trypsinized at subconfluency with $0.25 \%$ trypsin solution containing $0.01 \%$ ethyleendiaminetetraacetic acid (EDTA;invitrogen, Carlsbad, CA, USA) and re-plated at a density of 2300 cells $/ \mathrm{cm}^{2}$.

To evaluate whether different FCS batches or PL, generally used for MSC culturing, influence the migration or adhesion factor expression in MSCs, cryopreserved passage two MSCs ( $N=3$ donors) were used. MSC were expanded for one passage in three different 10\% FCS batches with three different lot numbers of the same company (Lonza, Verviers, Belgium, selected batches) and PL (>50 pooled human donors prepared as described previously ${ }^{33}$ ) in expansion medium. Before usage, PL was thawed and centrifuged at 2,000 g for $10 \mathrm{~min}$ to remove remaining platelet fragments. After centrifugation, PL was stored at $4^{\circ} \mathrm{C}$ and used for up to 1 week. After passaging the MSCs remained in their specific serum condition for another $72 \mathrm{~h}$ with a final medium change $24 \mathrm{~h}$ prior to harvesting for gene expression analysis.

To study the effect of OA SF and the effect of exposure to inflammatory factors and hypoxia, passage two MSCs were thawed and expanded for one passage. MSCs ( $\mathrm{N}=3$ donors) were plated in six well plates and at $70 \%$ confluence washed with PBS and cultured for $48 \mathrm{~h}$ in 
DMEM low glucose containing 20\% OA SF, $1 \%$ ITS, $1.5 \mu \mathrm{g} / \mathrm{ml}$ fungizone, $50 \mu \mathrm{g} / \mathrm{ml}$ gentamicin and $0.1 \mathrm{mM}$ of vitamin $\mathrm{C} .{ }^{29}$ After $48 \mathrm{~h}$ MSCs were harvested for gene expression analyses. To evaluate the effect of hypoxia and inflammatory factors, MSCs were plated in six well plates $\left(2 * 10^{5}\right.$ cells/well) and cultured in expansion medium for $48 \mathrm{~h}$ under $20 \%$ of oxygen (normoxic) or $1 \%$ of oxygen (hypoxic) conditions. After $48 \mathrm{~h}$, cells were washed with PBS and cultured for $24 \mathrm{~h}$ in DMEM low glucose containing 1\% ITS, $1.5 \mu \mathrm{g} / \mathrm{ml}$ fungizone, $50 \mu \mathrm{g} / \mathrm{ml}$ gentamicin and $0.1 \mathrm{mM}$ of vitamin $\mathrm{C}$ with additional $1 \mathrm{ng}, 20 \mathrm{ng}$ or $50 \mathrm{ng}$ of IFN $\gamma$ and TNF $\alpha$ (PeproTech, London, UK) per millilitre. MSCs while kept in their normoxic or hypoxic situation and subsequently were harvested for gene expression analyses, CM was harvested, centrifuged and stored at $-80{ }^{0} \mathrm{C}$. The choices for concentrations of inflammatory factors and exposure time to hypoxia and inflammatory factors have been made based on literature and own experiments. ${ }^{10}$, $11,40,47$

Gene expression analysis

Total RNA from MSCs was isolated using RNeasy® microkit with RNeasy MinElute spin columns (Qiagen, Hilden, Germany). After nucleic acids quantification by spectrophotometry (NanoDrop 2000, Thermo Scientific, IJsselstein, The Netherlands), RNA was reverse transcribed using a first strand cDNA synthesis kit (RevertAid ${ }^{\mathrm{TM}}$, MBI Fermentas, St. Leon-Rot, Germany). Amplifications were performed as $10 \mu \mathrm{L}$ reactions in CFX96 real-time thermal cycler (Bio-Rad Laboratories, Hercules, CA, USA). Thermocycler conditions comprised an initial holding at $95^{\circ} \mathrm{C}$ for $10 \mathrm{~min}$, followed by one step at $95^{\circ} \mathrm{C}$ for $15 \mathrm{~s}$ and $60^{\circ} \mathrm{C}$ for $60 \mathrm{~s}$ for 40 cycles. A dissociation stage was added at the end using $95^{\circ} \mathrm{C}$ for $15 \mathrm{~s}, 60^{\circ} \mathrm{C}$ for $20 \mathrm{~s}$ and $95^{\circ} \mathrm{C}$ for $15 \mathrm{~s}$. For 
HPRT TaqMan Master Mix (ABI, Branchburg, NJ, USA) was used. For receptor expression for chemotactic factors TaqMan universal Master Mix (Life Technologies, Bleiswijk, the Netherlands) was used for receptors $\mathrm{C}-\mathrm{C}$ chemokine receptor type 1 (CCRI), C-C Chemokine Receptor type 4 (CCR4), C-C Chemokine Receptor type 5 (CCR5), Platelet-Derived Growth Factor Receptor alpha (PDGFR $)$, Platelet-Derived Growth Factor Receptor beta (PDGFR $\beta)$, CXC Chemokine Receptor 1 (CXCR1), CXC Chemokine Receptor 3 (CXCR3), CXC Chemokine Receptor 4 (CXCR4), CX3C Chemokine Receptor 1/fractalkine receptor (CX3CR1) and adhesion factors Integrin beta-1 (ITGR1), Integrin beta-2 (ITGR2) and homing cell adhesion molecule CD44.. Primers and probes used in this study are depicted in table 1 . Genes were detected using TaqMan assays on demand (Life Technologies, Bleiswijk, the Netherlands). Data were quantitatively analysed on CFX manager ${ }^{\mathrm{TM}}$ software (version 3.1, Bio-Rad). Gene expressions in MSCs were calculated by cycle threshold (CT) values. CT values of $\geq 36$ were considered nonexpressed and set to 100 for further calculations. CT values were corrected for housekeeper gene HPRT by using the $2^{-\triangle C T}$ formula.

TABLE 1

Primers and probes used for Real-Time PCR

\begin{tabular}{llll}
\hline Genes & $\begin{array}{l}\text { Gene accession } \\
\text { number }\end{array}$ & $\begin{array}{l}\text { Predesign assay } \\
\text { number }\end{array}$ & Primer/probe \\
\hline $\begin{array}{l}\text { HPRT } \\
\text { (housekeeper) }\end{array}$ & NM_000194.2 & - & $\begin{array}{l}\text { Fw:TATGGACAGGACTGAACGTCTTG } \\
\text { Rv:CACACAGAGGGCTACAATGTG } \\
\text { FamAGATGTGATGAAGGAGATGGGAGGCCA } \\
\text { Assay on demand }\end{array}$ \\
CCR1 & NM_001295.2 & Hs00928897_s1 & Assay on demand \\
CCR5 & NM_005508.4 & Hs00747615_s1 & Assay on demand \\
CD44 & NM_001100168.1 & Hs99999149_s1 & Assay on demand \\
PDGFR & NM_000610.3 & Hs01075861_m1 & Assay on demand \\
PDGFR & NM_006206.4 & Hs00998018_m1 & Assay on demand
\end{tabular}




\begin{tabular}{llll} 
ITGB1 & NM_002211.3 & Hs00559595_m1 & Assay on demand \\
$I T G \beta 2$ & NM_000211.3 & Hs00164957_m1 & Assay on demand \\
CXCR1 & NM_000634.2 & Hs01921207_s1 & Assay on demand \\
CXCR3 & NM_001142797.1 & Hs01847760_s1 & Assay on demand \\
CXCR4 & NM_001008540.1 & Hs00607978_s1 & Assay on demand \\
CX3CR1 & NM_001171171.1 & Hs01922583_s1 & Assay on demand \\
\hline
\end{tabular}

\section{Migration assay}

The migration assays was performed with 24 well plate transwell inserts (Millicell@, inserts 8.0 $\mu \mathrm{m}$ PET, cat\# PIEP12R48, Merck Millipore, Temecula, CA, USA). OA cartilage CM (pooled from 6 donors), OA synovium CM (pooled from 6 donors) and control medium consisting of DMEM low glucose, $1 \% \mathrm{ITS}, 1.5 \mu \mathrm{g} / \mathrm{ml}$ fungizone, $50 \mu \mathrm{g} / \mathrm{ml}$ gentamicin, and $0.1 \mathrm{mM}$ of vitamin $\mathrm{C}$, were placed in the wells $(600 \mu 1 /$ well). Each condition was performed in six wells. Transwell inserts were placed in the wells and $6^{*} 10^{3}$ passage 2 MSCs in $200 \mu$ control medium were plated in the transwell insert and incubated for $18 \mathrm{~h}$. Then transwell inserts were harvested and the medium was discarded. The bottoms of the wells were checked for adherent MSCs to exclude missed migrated cells. The inserts were washed with PBS and cells on the insert membrane (inside and outside) were fixed with $10 \%$ formalin for $30 \mathrm{~min}$, permeabilized with $0.1 \%$ Triton X-100 for 5 min and washed with milliQ. Cells were stained by placing the inserts in toluidine blue for $60 \mathrm{~s}$ followed by a quick rinse in milliQ. The inner side of the membrane was swapped with a cotton wool swab to remove non migrated MSCs. Microscopic pictures of migrated MSCs to the outer side of the transwell membrane were taken directly after the swab. Migrated cells were counted at a 200x magnification using an inlay raster and nine pre-set standardized fields 
for the membranes. Based on these counts the total number of cells per square centimetres could be calculated and extrapolated to the total surface of the membrane. Hereby the number of migrated cells per condition could be determined. .

In vivo cell adhesion in OA knees and healthy rat knees

The animal experiments were approved by the animal ethical committee (EMC2285 116-11-03). The animals were housed in groups of 2 animals per IVC cage $(21 \times 37 \mathrm{~cm})$ in sawdust, enriched with nesting material. The animals had food and water ad libitum with a light/dark cycle of $12 \mathrm{~h}$. Discomfort and welfare were evaluated and scored daily by the animal caretakers. Animals were allocated to OA or control group at random. OA was induced bilaterally in the knees of 13 week old male wild-type Wistar rats $(\mathrm{N}=5)$ (Harlan Netherlands BV, Horst, the Netherlands) by an intra-articular injection of $20 \mu \mathrm{l}$ saline containing $1 \mathrm{mg}$ mono-iodo acetate (MIA). Healthy controls, 13 week old male wild-type Wistar rats $(\mathrm{N}=5)$ were bilaterally injected intraarticularly in the knee with $20 \mu \mathrm{l}$ saline. All injections and imaging procedures were applied under isoflurane inhalation anaesthesia (Pharmachemie BV, Haarlem, the Netherlands) while monitoring cardiac function, with additional subcutaneous injections of $0.01 \mathrm{mg} / \mathrm{kg}$ buprenorphine during and one day after intra-articular injections. MIA injections cause structural damage after three weeks ${ }^{42}$ and at that point MSCs were injected intra-articular.

Passage 3 MSCs were labelled at $80-90 \%$ confluency with superparamagnetic iron oxide (SPIO) by incubating the MSCs for $24 \mathrm{~h}$ in aMEM with 5\% FCS, ferumoxides $100 \mu \mathrm{g} / \mathrm{ml}(11.2 \mathrm{mg}$ $\mathrm{Fe} / \mathrm{ml}$, Endorem, lot/batch 08GE601A) and protamine sulphate $5 \mu \mathrm{g} / \mathrm{ml}$ (LEO Pharma). ${ }^{45}$ Labelled cells were trypzinized and plated at a density of $2 * 10^{4} \mathrm{MSCs} / \mathrm{cm}^{2}$. After $48 \mathrm{~h}$, MSCs 
were exposed to $50 \mathrm{ng} / \mathrm{ml} \mathrm{IFN} \gamma$ and TNF $\alpha$ in expansion medium or cultured in normal expansion medium (non-activated) for $24 \mathrm{~h}$. After $24 \mathrm{~h}$, MSCs were washed with PBS and trypzinized. $1 * 10^{6} \mathrm{MSCs}$ in $20 \mu \mathrm{l}$ saline were injected intra-articularly by using a $50 \mu \mathrm{l}$ syringe (Hamilton, Bonaduz, Switzerland). This number of $1 * 10^{6}$ MSCs was selected based on literature that reported effect of this cell number and side effects of higher number of cells. ${ }^{1,20,46} 24 \mathrm{~h}$ after injection SPIO-MSCs were visualized with a preclinical 7.0T MRI scanner (MR 901 Discovery, Agilent/GE Healthcare, Milwaukee, Wisconsin, USA) by using a fast spoiled gradient echo (FSPGR) sequence. TR/TE $=30 / 4 \mathrm{~ms}$, slice thickness $0.4 \mathrm{~mm}$, matrix 192x192, FOV $5 \mathrm{~cm}, 2$ averages, flip angle 16. Cell attachment and migration were evaluated after $24 \mathrm{~h}$ of injection since we expected attachment and migration processes to take place in these 24 hours. Directly after the scan, the rats were sacrificed by a pentobarbital overdose and the knees were harvested for histology. 24 hours to evaluate cell migration and attachment to the tissue. These processes are expected to take place in the first 24 hours

\section{Tissue Harvest and Histologic Evaluations}

All knees $(\mathrm{N}=20$ knees) were fixed in formalin $4 \%(\mathrm{v} / \mathrm{v})$ at room temperature for 1 week, decalcified in $10 \%$ EDTA at room temperature for 3 weeks and embedded in paraffin. Coronal sections were stained with Thionin to evaluate cartilage damage. ${ }^{46}$ Perl's iron staining was done for localization of SPIO-MSCs. All samples were blinded before scoring and two different histology sections of each knee were scored by two researchers. Disagreements of greater than 1 point were resolved by consensus. Consultation of a third researcher when disagreement persisted, appeared unnecessary. The average score of MSC attachment of both researchers is 
depicted in figure 4. To confirm osteoarthritis, cartilage quality was scored on the patella, trochlea, tibia plateau and femoral condyles with a modified Pritzker score. ${ }^{36,46}$ An average score for GAG loss and structural damage was calculated. To score the amount of injected MSCs that adhered to different tissues in the joint we used a semi quantitative scoring system on the Perl's iron histology. 1: <10 MSCs; 2:10-50 MSCs; 3: 50-250 MSCs; 4: 250-1000 MSCs; 5:>1000 MSCs. Locations of the injected MSCs were divided in synovium, cartilage and non-adherent in the joint space.

\section{Statistics}

Effects of different FCS batches. PL, inflammatory factors, hypoxia and OA SF on gene expression of chemotactic receptors genes were analyzee with a mixed model ANOVA, which takes correlation within donors into account. Analysis of cell migration was done with a separate ANOVA linear regression model for MSCs with and without being exposed to inflammatory factors. Posthoc, independent two-tailed T-tests were performed to compare conditions within both groups. The effect of MIA on MSC adhesion to different OA tissues in vivo was done by independent two-tailed T-tests. P-values of $\leq 0.05$ were considered statistical significant. Analyses were performed using SPSS 21.0 Statistics (SPSS Inc., Chicago, IL, USA).

\section{Results}

Chemokines in the synovial fluid and secreted by OA tissues in vitro 
To evaluate chemokine secretion by cartilage and synovium, we did a 10-plex milliplex assay on $\mathrm{CM}$ of OA synovium and cartilage, and on OA SF. The ten selected factors were detected in all conditions (Table 2). High levels of MCP-1 and IL-8 were secreted by synovium and cartilage. Furthermore, synovium secreted high amounts of MIP-1a and MIP-1b, whereas cartilage secreted high amounts of PDGF-AA and IP-10. mRNA of the receptors for these chemokines were expressed in cultured MSCs. CD44, PDGFR $\alpha$ and $P D G F R \beta$ were highly expressed $(\mathrm{CT} \leq$ 25), CCR1, CCR4, CCR5, CXCR3 and CX3CR1 were intermediately expressed (CT = $26-36)$ and $C X C R 1$ was not expressed $(\mathrm{CT} \geq 36)$.

\section{TABLE 2}

Chemokine secretion by osteoarthritic synovium and cartilage

\begin{tabular}{|c|c|c|c|c|}
\hline Chemokine & $\begin{array}{l}\text { OA synovium CM } \\
\text { (mean and range) }\end{array}$ & $\begin{array}{l}\text { OA cartilage } \mathrm{CM} \\
\text { (mean and range) }\end{array}$ & $\begin{array}{l}\text { OA synovial fluid } \\
\text { (mean and range) }\end{array}$ & $\begin{array}{c}\text { Minimum } \\
\text { DC (pg/ml) }\end{array}$ \\
\hline MCP-1 & $31,753 \quad(15,689-63,264)$ & $3,499.4(1,344.6-6,040.8)$ & $3,276.6(847.4-4,935.5)$ & 1.9 \\
\hline IL-8 & $116,848(63,634-197,030)$ & $3,548.3(114.0-11,826)$ & $170.2 \quad(27.4-463.5)$ & 0.4 \\
\hline MIP-1a & $309.1 \quad(48.6-1,077.4)$ & $12.7 \quad(3.2-23.9)$ & $(1.5-11.8)$ & 2.9 \\
\hline MIP-1b & $367.2 \quad(73.4-718.0)$ & $(5.8-57.1)$ & $(24.8-197.1)$ & 3.0 \\
\hline PDGF-AA & $(4.9-32.2)$ & $258.3 \quad(115.1-513.5)$ & $104.9 \quad(26.7-229.0)$ & 0.4 \\
\hline IP-10 & $139.1 \quad(4.3-425.5)$ & $1,014.0(171.5-3,297.1)$ & $4,661.8 \quad(2,223.9-7,907.7)$ & 8.6 \\
\hline MDC & $(29.4-197.4)$ & $146.4 \quad(104.7-168.4)$ & $234.8 \quad(137.0-369.5)$ & 3.6 \\
\hline MCP-3 & $(1.9-47.2)$ & $(1.9-14.7)$ & $66.4 \quad(1.9-263.6)$ & 3.8 \\
\hline PDGF-AB/BB & $(1.1-318.9)$ & $(1.1-6.1)$ & $799.0 \quad(417.4-1,706.2)$ & 2.2 \\
\hline Fractalkine & $434.8 \quad(213.9-795.2)$ & $(11.4-34.8)$ & $111.6 \quad(11.4-208.3)$ & 22.7 \\
\hline
\end{tabular}

Chemokine secretion by osteoarthritic synovium and cartilage for 24 hours in medium and

chemokine content in osteoarthritic synovial fluid in $\mathrm{pg} / \mathrm{ml}$. Undetectable and below minimum detectable concentrations values were set at $50 \%$ of the minimum detectable concentration value. Data are indicated as mean with range. $N=6$ donors. Minimum detectable concentrations pg/ml (Minimum DC), osteoarthritis (OA), conditioned medium (CM). 
During culture the MSC are generally exposed to serum. Different laboratories use different batches of fetal calf serum (FCS). Moreover, the use of pooled batches of human platelet lysate (PL) becomes increasingly popular. Serum could potentially influence cell behaviour and could make comparison between results obtained in different laboratories difficult. We evaluated the expression of known migration receptors $P D G F R \alpha, P D G F R \beta, C C R 1$ and $C C R 4$, and adhesion receptors $I T G \beta 1, I T G \beta 2$, and $C D 44$, in MSCs expanded in 3 different batches of FCS and a
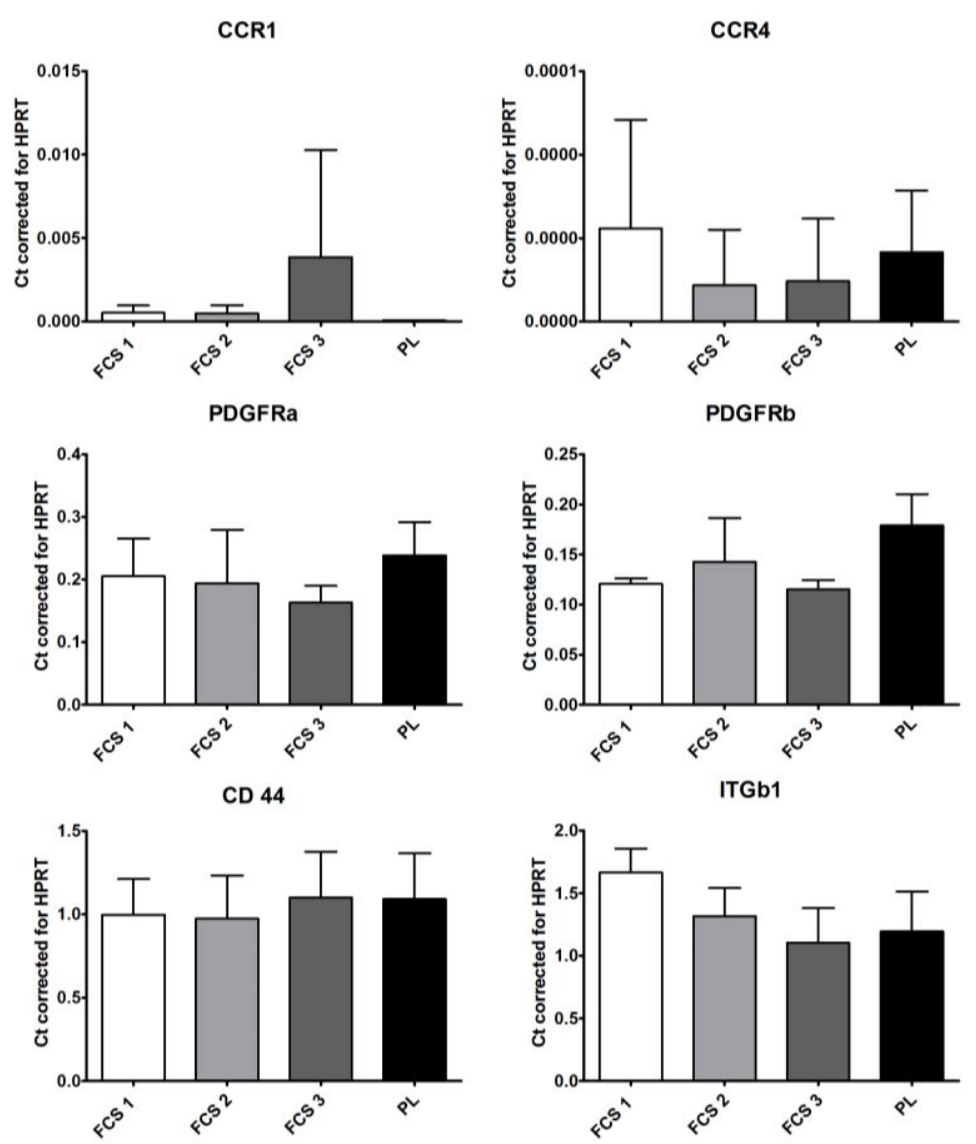

batch of pooled human PL. Different culture sera did not significantly affect the expression of migration receptors $C C R 1, C C R 4, P D G F R \alpha$ and $P D G F R \beta$ or the expression of the adhesion receptors $C D 44$ and ITG $\beta 1$ in MSCs (Figure 1).

Figure 1. The expression of migration and adhesion receptors in MSCs is culture serum independent. Culturing MSCs ( $\mathrm{N}=3$ donors with triplicate samples for each donor) with 3 
different batches of FCS in the expansion medium or with a batch of pooled human PL (N $=>50$ donors) in the expansion medium. Data shown as mean \pm SD; Fetal calf serum (FCS), platelet lysate (PL).

Influence of inflammation, hypoxia and OA synovial fluid on MSC migration/adhesion receptors To evaluate whether a short treatment in culture could increase expression of migration or adhesion receptor genes in MSCs, we exposed the cells to inflammatory factors IFN $\gamma / \mathrm{TNF} \alpha$ or cultured them in hypoxia $(1 \%$ O2). Furthermore, we determined whether OA SF would influence expression of the before mentioned genes. Exposure of MSCs to different concentrations of IFN $\gamma / \mathrm{TNF} \alpha$ upregulated the expression of $C C R 1, C C R 4$ and $C D 44$, whereas PDGFR and PDGFR $\beta$ were downregulated by the inflammatory factors (Figure 2). The other migration receptor genes, CCR5, CXCR1, CXCR3, CXCR4 and CX3CR1, and adhesion receptor genes ITG $\beta 1$ and ITG $\beta 2$, were not influenced by inflammatory factors (data not shown). Hypoxia did not have any effect on the gene expression of the migration receptors and adhesion receptors studied, neither in the presence or absence of IFN $\gamma / \mathrm{TNF} \alpha$ (Supplementary figure 1). Finally, we only observed an upregulation of gene expression of $P D G F R \beta(\mathrm{P}=0.006)$ in MSCs by OA SF (supplementary figure 2) 

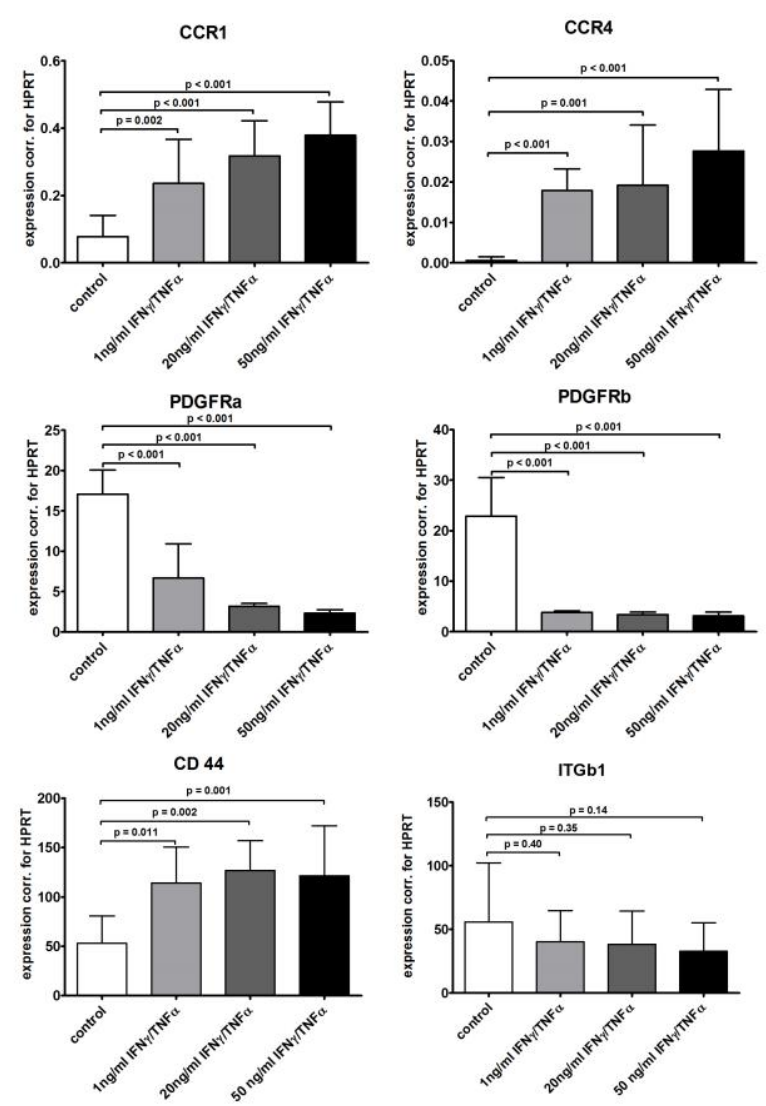

Figure 2. Gene expression of migration and adhesion receptors in MSCs after exposure to inflammatory factors IFN $\gamma / \mathrm{TNF} \alpha$ for $24 \mathrm{~h} . \mathrm{N}=3 \mathrm{MSC}$ donors with triplicate samples for each donor. Data shown as mean $\pm \mathrm{SD}$.

MSC migration towards factors secreted by OA tissues 
We evaluated whether MSCs would migrate to factors secreted by OA synovium or cartilage and whether this was influenced by pre-treatment of MSCs with IFN $\gamma / \mathrm{TNF} \alpha$. MSCs migrated more towards $\mathrm{OA}$ synovium $\mathrm{CM}$ and $\mathrm{OA}$ cartilage $\mathrm{CM}$ compared to control medium for both non-

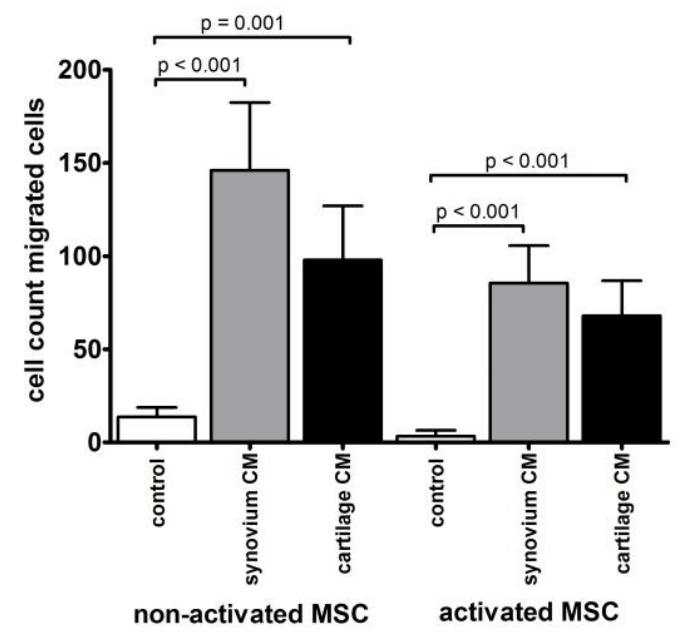

activated $(\mathrm{P} \leq 0.001)$ and activated MSCs $(\mathrm{P}<0.001)$, indicating that $\mathrm{OA}$ cartilage and synovium secreted factors which stimulated MSC migration (Figure 3). No significant effect of pretreatment of MSCs was found $(\mathrm{P}=0.060)$. Non-activated MSCs migrated more towards synovium CM compared to cartilage CM $(\mathrm{P}=0.031)$, a comparable trend was observed for MSC activated by inflammatory factors $(\mathrm{P}=0.065)$.

Figure 3. MSC migration towards factors secreted by OA synovium and OA cartilage in a transwell migration assay. Data shown as mean $\pm \mathrm{SD}$; Conditioned medium $(\mathrm{CM})$, non-activated MSCs $=24 \mathrm{~h}$ refreshment of medium; activated MSCs $=$ MSCs $24 \mathrm{~h}$ activated with $50 \mathrm{ng} / \mathrm{ml}$ IFN $\gamma / \mathrm{TNF} \alpha$ in medium.

In vivo adhesion of non-activated MSCs and activated MSCs in healthy knees or OA knees.

An in vivo experiment was performed to study MSC migration and attachment to synovium and cartilage. All animals used were healthy wild-type Wistar male rats prior to the study and no side 
effects or health problems were found during the study. We evaluated if there was a difference between activated and non-activated MSCs in their migration and adherence patterns and whether this was influenced by the presence or absence of OA. MSCs were found attached to synovium, cartilage or freely in the joint space (Fig 4 E). Cartilage damage and synovial inflammation were clearly visible after OA induction by the MIA model (modified Pritzker score $20.4 \pm 4.84$ ) and absent in control knees (modified Pritzker score $4.4 \pm 1.27)(\mathrm{P}<0.001)$ (Figure 4A, 4B). $24 \mathrm{~h}$ after injection MSCs were present in all control and OA knees. MSCs were mostly found attached to synovium (semi quantitative score $3.13 \pm 1.19$ ) or freely in the joint space (semi quantitative score $3.95 \pm 1.25$ ), this was approximately equally distributed based on our semi-quantitative scoring system. Since very small amounts of cells were found attached to cartilage (semi quantitative score $1.03 \pm 0.11$ ) (Figure 4D), we only evaluated MSC attachment to synovium to compare healthy vs OA knees and to evaluate the effect of MSC pre-treatment with inflammatory factors. We could not detect significant differences in MSC attachment to synovium between $\mathrm{OA}$ and healthy knees nor an effect of pre-treatment with inflammatory factors (Figure 4F, 4G). 

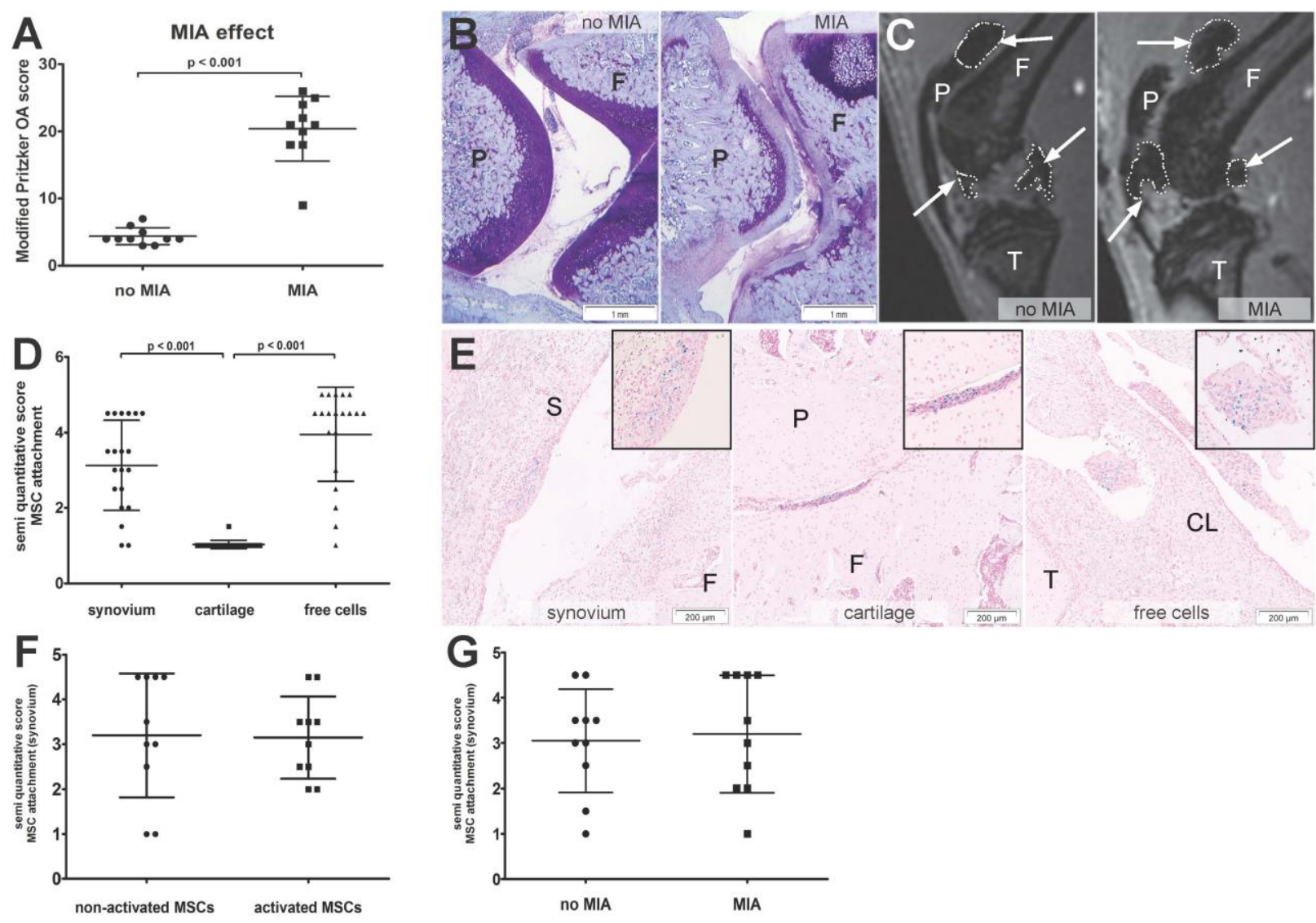

Figure 4. In vivo adherence of non-activated MSCs and activated MSCs in healthy knees or OA knees. OA was bilateral induced in rat knees ( $\mathrm{N}=10$ knees) with a MIA injection. Healthy rat knees ( $\mathrm{N}=10$ knees) were used as control. (A) Modified Pritzker OA score on histology of 20 rat knees. (B) Thionin staining on coronal knee histology sections with a control knee (left side) and MIA induced OA knee (right side). (C) Arrows indicate SPIO labelled MSC on MRI in a control knee (left side) and OA knee (right side). (D) Semi quantitative score of MSC attachment on synovium and cartilage, (control and OA knees combined). (E) Perl's iron staining on coronal knee histology was done to localize intra-articular injected MSCs. From left to right: histological samples of attached MSCs to synovium, cartilage and free cells in the joint space. The upper right corner shows an enlargement of the attached cells. (F) Comparison between the attachment of activated and non-activated MSCs to synovium in all knees. (G) Difference between control 
and OA knees in the migration of MSCs towards synovium . Data is shown as mean $\pm \mathrm{SD}$; patella $(\mathrm{P})$, femur $(\mathrm{F})$, tibia $(\mathrm{T})$, synovium $(\mathrm{S})$, cruciate ligament $(\mathrm{CL})$, osteoarthritis (OA), nonactivated $=$ MSCs $24 \mathrm{~h}$ refreshment of medium, activated $=$ MSCs $24 \mathrm{~h}$ activated with $50 \mathrm{ng} / \mathrm{ml}$ IFN $\gamma / \mathrm{TNF} \alpha$ in medium, mono-iodo acetate (MIA).

\section{Discussion}

We investigated whether MSCs migrate to OA tissues and if this migration could be influenced by adapting the culture conditions before application of MSCs. Both OA synovium and OA cartilage secreted substantial amounts of chemokines. The profile of the secreted chemokines varied between both tissues. We showed that MSCs express migration and adhesion receptor genes and migrate to factors secreted by both OA synovium and cartilage in vitro. In vivo more MSCs attached to synovium than to cartilage. The expression of migration and adhesion receptors was altered by adding inflammatory factors during culture, albeit this did not influence migration in vitro nor adhesion in vivo.

Throughout the world, laboratories use different batches of FCS to culture MSCs. Nowadays human PL is often used and is described to have a positive effect on proliferation and differentiation of MSCs. ${ }^{25}$ However, contradictory results have been published regarding the effect of culturing with PL on the migration/adhesion capacity of MSCs and the migration of MSCs towards PL. ${ }^{17,}{ }^{33}$ We compared the effects of 3 different batches of FCS and a batch of pooled PL on gene expression of migration and adhesion receptors in MSCs. Our results indicate that different FCS batches or PL will not likely have a differential effect on migration and attachment of MSCs, making different sera in expansion culture less likely to be a confounder 
for migration and adhesion in the comparison of different studies with intra-articularly injected MSCs.

Next to MSC capacities to differentiate and regenerate damaged tissue, their immunomodulatory and trophic properties are very important for their therapeutic function in OA. MSCs need to be activated with inflammatory factors like IFN $\gamma$ and TNF $\alpha$ to secrete immunomodulatory and trophic factors. ${ }^{15,28,38,41}$ This immunomodulatory and trophic capacity is maintained under hypoxic conditions, ${ }^{30,40}$ which is important because MSCs as cell therapy for OA will be injected in a hypoxic joint environment. We showed no effect of hypoxia on the expression of migration or adhesion receptor genes in MSCs. It is not clear what the levels of hypoxia are in joints, but for culture, hypoxia levels range from 1-5\% of oxygen. We chose $1 \%$ of oxygen based on previous studies and experiments in our laboratory. ${ }^{10,40}$ When using a different oxygen level this might have different effects. It is known that inflammatory factors can upregulate chemokine receptors in MSCs in vitro. ${ }^{16,18,35,37}$ We hypothesized that these inflammatory factors could also improve their migration to and adhesion on $\mathrm{OA}$ tissues. Indeed, inflammatory factors IFN $\gamma / \mathrm{TNF} \alpha$ upregulated gene expression of $C C R 1$ and $C C R 4$, although PDGFR $\alpha$ and PDGFR $\beta$ were downregulated. Chemokines that bind to CCR1 and CCR4 (i.e. MIP-1a, MIP1b, MCP-1, MCP-3) were found in a higher concentration in synovium CM compared to cartilage CM. These chemokines can increase MSC migration. ${ }^{7}$ Since the receptors that bind these chemokines are upregulated in MSCs by activation with IFN $\gamma / \mathrm{TNF} \alpha$, we would expect better attachment and migration to synovium after MSC activation. Nevertheless, this was not confirmed in vitro or in vivo where cell activation with IFN $\gamma$ and TNF $\alpha$ did not improve functional migration of MSCs to synovium. PDGF $\beta$, a chemokine that binds to PDGFR $\beta$ and indirectly interacts with PDGFR $\alpha$, was more abundantly found in cartilage CM. There was less MSC attachment and migration to 
cartilage, although activation with IFN $\gamma$ and $\mathrm{TNF} \alpha$ did not decrease the cell attachment and migration. These results are in line with a recent report on MSC homing in a mouse hypoxic gut model. ${ }^{26}$ We cannot exclude that longer or shorter exposure to culture conditions or different concentrations of inflammatory factors or oxygen might have had an effect. In our study, the absolute migration was even slightly decreased in vitro, albeit the activated cells still migrated towards factors secreted by OA tissues. We excluded that cell death due to treatment with 50 ng/ml IFN $\gamma / \mathrm{TNF} \alpha$ could be an explanation of the decreased absolute migration found, sinceexposure to these factors did not decrease cell survival after $24 \mathrm{~h}$. We have, however, not evaluated whether the immunomodulatory properties of MSCs pre-treated with IFN $\gamma / \mathrm{TNF} \alpha$ were indeed increased in vivo. This will need careful consideration before future applications since, Kavanagh et al. recently found a decreased vasculoprotective effect in vivo of MSCs pre-treated with IFN $\gamma$ or TNF ${ }^{26}$

There are several limitations to our study. We have used human MSCs from relatively aged OA donors who underwent total hip arthroplasty. Although these MSCs might be considered less potent in vivo compared to rat MSC from young donors, we consider this cell type to be more clinically relevant, being better predictive for expected results in future clinical application. We have used cartilage and synovium of six different donors and MSCs of three donors. Donor variability should always be taken into account. The level and the variation we have seen in the chemokine data are comparable with the variation we have seen in previous studies. ${ }^{6,9}$ The effect of inflammatory factors or hypoxia on chemokine and adhesion receptor expression was not large on all MSC donors. Therefore, we consider our conclusions valid. Furthermore, cells were labelled using SPIO for tracking purposes by MRI and histology. SPIO labelling could have an effect on cell migration and adhesion capacities. ${ }^{12,52}$ Although we did not find effects of our 
labelling procedure of cell viability, differentiation and secretion of immunomodulatory factors in previous studies ${ }^{47}$, and we confirmed the cells were viable and adherent when cultured on tissue culture plastic, we cannot completely rule out an effect. Migration and adherence of the cells was evaluated 24 hours after injection. These processes are expected to take place in the first 24 hours. We realize that this time window is not sufficient to study the many processes that might happen afterwards, such as cell proliferation, cell invasion into tissues and cell death. We assume that cells will not attach when they have died during injection or during the first hours after injection. The attached cells were scored on histology by a semi quantitative score which can be not accurate enough to quantify eventual differences between the groups.

MSCs migrated more towards factors secreted by OA synovium compared to cartilage. In line with this, more cells attached to synovium than to cartilage in vivo. This could be explained by both chemo-attractive and mechanic processes. Overall, chemotactic factors were found in a higher concentration in synovial CM compared to cartilage CM. Care should be taken however, to directly compare the levels of factors secreted by synovium and cartilage in our studies. Although synovium CM and cartilage CM were made in a standardized way, based on wet weight tissue per volume, synovial tissue contains substantially more cells per gram wet weight than cartilage tissue. Nevertheless, we can conclude that both synovium and cartilage secrete high amounts of chemokines, and the profile of the secreted chemokines seems to differ between synovium and cartilage. The factors secreted by cartilage and synovium were also found in synovial fluid. In a previous study we found that the levels of MDC, PDGF-AA, IP-10, CCL5, MIP-1b were higher in $\mathrm{OA}$ than in control $\mathrm{SF}^{6}$, which would be indicative for higher chemotactic effects of osteoarthritic tissues. Nevertheless, no differences in migration or adhesion was seen between rat knees with and without OA. The synovial fluid did not affect the 
receptor gene expression in MSCs (supplementary figure 2), but we did not evaluate whether the secreted factors individually could affect the gene expression or function of MSCs. Another explanation for better adhesion of MSCs to synovium compared to cartilage could be the continuous movements of the joint that might evoke shear stresses that MSCs cannot resist, especially those who primarily attached to cartilage. Furthermore, cells are more likely to attach to a rough surface like synovium than to a smooth surface like cartilage. Nevertheless, in our OA model with marked cartilage damage, no improvement of cell adhesion to cartilage was seen. We assume that intra-articular cell attachment is influenced by a combination of chemo-attractive processes, tissue surface characteristics and biomechanics.

\section{Conclusion}

Intra-articular tissues affected by OA secrete chemotactic factors that can attract MSCs. Exposure to inflammatory factors did influence MSC gene expression of several chemokine receptors while these inflammatory factors did not affect the migration of MSCs in vitro or MSC attachment in vivo. .

\section{References}

1. Agung M, Ochi M, Yanada S, et al. Mobilization of bone marrow-derived mesenchymal stem cells into the injured tissues after intraarticular injection and their contribution to tissue regeneration. Knee Surg Sports Traumatol Arthrosc. 2006;14(12):1307-1314.

2. Ajuied A, Wong F, Smith C, et al. Anterior cruciate ligament injury and radiologic progression of knee osteoarthritis: a systematic review and meta-analysis. Am J Sports Med. 2014;42(9):22422252.

3. Augello A, Kurth TB, De Bari C. Mesenchymal stem cells: a perspective from in vitro cultures to in vivo migration and niches. Eur Cell Mater. 2010;20:121-133.

4. Barry F, Murphy M. Mesenchymal stem cells in joint disease and repair. Nat Rev Rheumatol. 2013;9(10):584-594. 
5. Beekhuizen M, Bastiaansen-Jenniskens YM, Koevoet W, et al. Osteoarthritic synovial tissue inhibition of proteoglycan production in human osteoarthritic knee cartilage: establishment and characterization of a long-term cartilage-synovium coculture. Arthritis Rheum. 2011;63(7):19181927.

6. Beekhuizen M, Gierman LM, van Spil WE, et al. An explorative study comparing levels of soluble mediators in control and osteoarthritic synovial fluid. Osteoarthritis Cartilage. 2013.

7. Boomsma RA, Geenen DL. Mesenchymal stem cells secrete multiple cytokines that promote angiogenesis and have contrasting effects on chemotaxis and apoptosis. PLoS One. 2012;7(4):e35685.

8. Caplan AI. Why are MSCs therapeutic? New data: new insight. J Pathol. 2009;217(2):318-324.

9. Clockaerts S, Bastiaansen-Jenniskens YM, Feijt C, et al. Cytokine production by infrapatellar fat pad can be stimulated by interleukin 1beta and inhibited by peroxisome proliferator activated receptor alpha agonist. Ann Rheum Dis. 2012;71(6):1012-1018.

10.Das R, Jahr H, van Osch GJ, Farrell E. The role of hypoxia in bone marrow-derived mesenchymal stem cells: considerations for regenerative medicine approaches. Tissue Eng Part B Rev. 2010;16(2):159-168.

11.de Witte SF, Franquesa M, Baan CC, Hoogduijn MJ. Toward Development of iMesenchymal Stem Cells for Immunomodulatory Therapy. Front Immunol. 2015;6:648.

12. Diana V, Bossolasco P, Moscatelli D, Silani V, Cova L. Dose dependent side effect of superparamagnetic iron oxide nanoparticle labeling on cell motility in two fetal stem cell populations. PLoS One. 2013;8(11):e78435.

13. Docheva D, Popov C, Mutschler W, Schieker M. Human mesenchymal stem cells in contact with their environment: surface characteristics and the integrin system. J Cell Mol Med. 2007;11(1):21-38.

14.Dong F, Harvey J, Finan A, Weber K, Agarwal U, Penn MS. Myocardial CXCR4 expression is required for mesenchymal stem cell mediated repair following acute myocardial infarction. Circulation. 2012;126(3):314-324.

15.English K, Barry FP, Field-Corbett CP, Mahon BP. IFN-gamma and TNF-alpha differentially regulate immunomodulation by murine mesenchymal stem cells. Immunol Lett. 2007;110(2):91-100.

16.Eseonu OI, De Bari C. Homing of mesenchymal stem cells: mechanistic or stochastic? Implications for targeted delivery in arthritis. Rheumatology (Oxford). 2015;54(2):210-218.

17.Goedecke A, Wobus M, Krech M, et al. Differential effect of platelet-rich plasma and fetal calf serum on bone marrow-derived human mesenchymal stromal cells expanded in vitro. J Tissue Eng Regen Med. 2011;5(8):648-654.

18. Hemeda H, Jakob M, Ludwig AK, Giebel B, Lang S, Brandau S. Interferon-gamma and tumor necrosis factor-alpha differentially affect cytokine expression and migration properties of mesenchymal stem cells. Stem Cells Dev. 2010;19(5):693-706.

19. Honczarenko M, Le Y, Swierkowski M, Ghiran I, Glodek AM, Silberstein LE. Human bone marrow stromal cells express a distinct set of biologically functional chemokine receptors. Stem Cells. 2006;24(4):1030-1041.

20.Horie M, Sekiya I, Muneta T, et al. Intra-articular Injected synovial stem cells differentiate into meniscal cells directly and promote meniscal regeneration without mobilization to distant organs in rat massive meniscal defect. Stem Cells. 2009;27(4):878-887.

21.Huang J, Zhang Z, Guo J, et al. Genetic modification of mesenchymal stem cells overexpressing CCR1 increases cell viability, migration, engraftment, and capillary density in the injured myocardium. Circ Res. 2010;106(11):1753-1762.

22.Hung SC, Pochampally RR, Hsu SC, et al. Short-term exposure of multipotent stromal cells to low oxygen increases their expression of CX3CR1 and CXCR4 and their engraftment in vivo. PLoS One. 2007;2(5):e416.

23.Ip JE, Wu Y, Huang J, Zhang L, Pratt RE, Dzau VJ. Mesenchymal stem cells use integrin beta1 not CXC chemokine receptor 4 for myocardial migration and engraftment. Mol Biol Cell. 2007;18(8):2873-2882. 
24.Ji JF, He BP, Dheen ST, Tay SS. Interactions of chemokines and chemokine receptors mediate the migration of mesenchymal stem cells to the impaired site in the brain after hypoglossal nerve injury. Stem Cells. 2004;22(3):415-427.

25.Jonsdottir-Buch SM, Sigurgrimsdottir H, Lieder R, Sigurjonsson OE. Expired and pathogen inactivated platelet concentrates support differentiation and immunomodulation of mesenchymal stromal cells in culture. Cell Transplant. 2014.

26. Kavanagh DP, Suresh S, Newsome PN, Frampton J, Kalia N. Pretreatment of Mesenchymal Stem Cells Manipulates Their Vasculoprotective Potential While Not Altering Their Homing Within the Injured Gut. Stem Cells. 2015.

27.Kim YS, Kwon OR, Choi YJ, Suh DS, Heo DB, Koh YG. Comparative Matched-Pair Analysis of the Injection Versus Implantation of Mesenchymal Stem Cells for Knee Osteoarthritis. Am J Sports Med. 2015.

28. Krampera M, Cosmi L, Angeli R, et al. Role for interferon-gamma in the immunomodulatory activity of human bone marrow mesenchymal stem cells. Stem Cells. 2006;24(2):386-398.

29.Leijs MJ, van Buul GM, Lubberts E, et al. Effect of Arthritic Synovial Fluids on the Expression of Immunomodulatory Factors by Mesenchymal Stem Cells: An Explorative in vitro Study. Front Immunol. 2012;3:231.

30. Markway BD, Tan GK, Brooke G, Hudson JE, Cooper-White JJ, Doran MR. Enhanced chondrogenic differentiation of human bone marrow-derived mesenchymal stem cells in low oxygen environment micropellet cultures. Cell Transplant. 2010;19(1):29-42.

31. Mathieu E, Lamirault G, Toquet $\mathrm{C}$, et al. Intramyocardial delivery of mesenchymal stem cell-seeded hydrogel preserves cardiac function and attenuates ventricular remodeling after myocardial infarction. PLoS One. 2012;7(12):e51991.

32. Murphy JM, Fink DJ, Hunziker EB, Barry FP. Stem cell therapy in a caprine model of osteoarthritis. Arthritis Rheum. 2003;48(12):3464-3474.

33. Naaijkens BA, Niessen HW, Prins HJ, et al. Human platelet lysate as a fetal bovine serum substitute improves human adipose-derived stromal cell culture for future cardiac repair applications. Cell Tissue Res. 2012;348(1):119-130.

34.Peeters CM, Leijs MJ, Reijman M, van Osch GJ, Bos PK. Safety of intra-articular cell-therapy with culture-expanded stem cells in humans: a systematic literature review. Osteoarthritis Cartilage. 2013;21(10):1465-1473.

35.Ponte AL, Marais E, Gallay $\mathrm{N}$, et al. The in vitro migration capacity of human bone marrow mesenchymal stem cells: comparison of chemokine and growth factor chemotactic activities. Stem Cells. 2007;25(7):1737-1745.

36.Pritzker KP, Gay S, Jimenez SA, et al. Osteoarthritis cartilage histopathology: grading and staging. Osteoarthritis Cartilage. 2006;14(1):13-29.

37.Ren G, Roberts AI, Shi Y. Adhesion molecules: key players in Mesenchymal stem cell-mediated immunosuppression. Cell Adh Migr. 2011;5(1):20-22.

38.Ren G, Zhang L, Zhao X, et al. Mesenchymal stem cell-mediated immunosuppression occurs via concerted action of chemokines and nitric oxide. Cell Stem Cell. 2008;2(2):141-150.

39.Ringe J, Strassburg S, Neumann K, et al. Towards in situ tissue repair: human mesenchymal stem cells express chemokine receptors CXCR1, CXCR2 and CCR2, and migrate upon stimulation with CXCL8 but not CCL2. J Cell Biochem. 2007;101(1):135-146.

40. Roemeling-van Rhijn M, Mensah FK, Korevaar SS, et al. Effects of Hypoxia on the Immunomodulatory Properties of Adipose Tissue-Derived Mesenchymal Stem cells. Front Immunol. 2013;4:203.

41.Ryan JM, Barry F, Murphy JM, Mahon BP. Interferon-gamma does not break, but promotes the immunosuppressive capacity of adult human mesenchymal stem cells. Clin Exp Immunol. 2007;149(2):353-363. 
42. Siebelt M, Waarsing JH, Kops N, et al. Quantifying osteoarthritic cartilage changes accurately using in vivo microCT arthrography in three etiologically distinct rat models. J Orthop Res. 2011;29(11):1788-1794.

43. Sordi V, Malosio ML, Marchesi F, et al. Bone marrow mesenchymal stem cells express a restricted set of functionally active chemokine receptors capable of promoting migration to pancreatic islets. Blood. 2005;106(2):419-427.

44.ter Huurne M, Schelbergen R, Blattes R, et al. Antiinflammatory and chondroprotective effects of intraarticular injection of adipose-derived stem cells in experimental osteoarthritis. Arthritis Rheum. 2012;64(11):3604-3613.

45.van Buul GM, Farrell E, Kops N, et al. Ferumoxides-protamine sulfate is more effective than ferucarbotran for cell labeling: implications for clinically applicable cell tracking using MRI. Contrast Media Mol Imaging. 2009;4(5):230-236.

46.van Buul GM, Siebelt M, Leijs MJ, et al. Mesenchymal stem cells reduce pain but not degenerative changes in a mono-iodoacetate rat model of osteoarthritis. J Orthop Res. 2014;32(9):1167-1174.

47.van Buul GM, Villafuertes E, Bos PK, et al. Mesenchymal stem cells secrete factors that inhibit inflammatory processes in short-term osteoarthritic synovium and cartilage explant culture. Osteoarthritis Cartilage. 2012;20(10):1186-1196.

48.Vega A, Martin-Ferrero MA, Del Canto F, et al. Treatment of Knee Osteoarthritis With Allogeneic Bone Marrow Mesenchymal Stem Cells: A Randomized Controlled Trial. Transplantation. 2015.

49.Wang $\mathrm{T}$, Jiang XJ, Tang QZ, et al. Bone marrow stem cells implantation with alphacyclodextrin/MPEG-PCL-MPEG hydrogel improves cardiac function after myocardial infarction. Acta Biomater. 2009;5(8):2939-2944.

50. Whittaker JL, Woodhouse LJ, Nettel-Aguirre A, Emery CA. Outcomes associated with early posttraumatic osteoarthritis and other negative health consequences 3-10 years following knee joint injury in youth sport. Osteoarthritis Cartilage. 2015;23(7):1122-1129.

51.Wu Y, Zhao RC. The role of chemokines in mesenchymal stem cell homing to myocardium. Stem Cell Rev. 2012;8(1):243-250.

52. Yang JX, Tang WL, Wang XX. Superparamagnetic iron oxide nanoparticles may affect endothelial progenitor cell migration ability and adhesion capacity. Cytotherapy. 2010;12(2):251-259.

53.Zhang X, Wang H, Ma X, et al. Preservation of the cardiac function in infarcted rat hearts by the transplantation of adipose-derived stem cells with injectable fibrin scaffolds. Exp Biol Med (Maywood). 2010;235(12):1505-1515.

54.Zwolanek D, Flicker M, Kirstatter E, Zaucke F, van Osch GJ, Erben RG. beta1 Integrins Mediate Attachment of Mesenchymal Stem Cells to Cartilage Lesions. Biores Open Access. 2015;4(1):3953. 

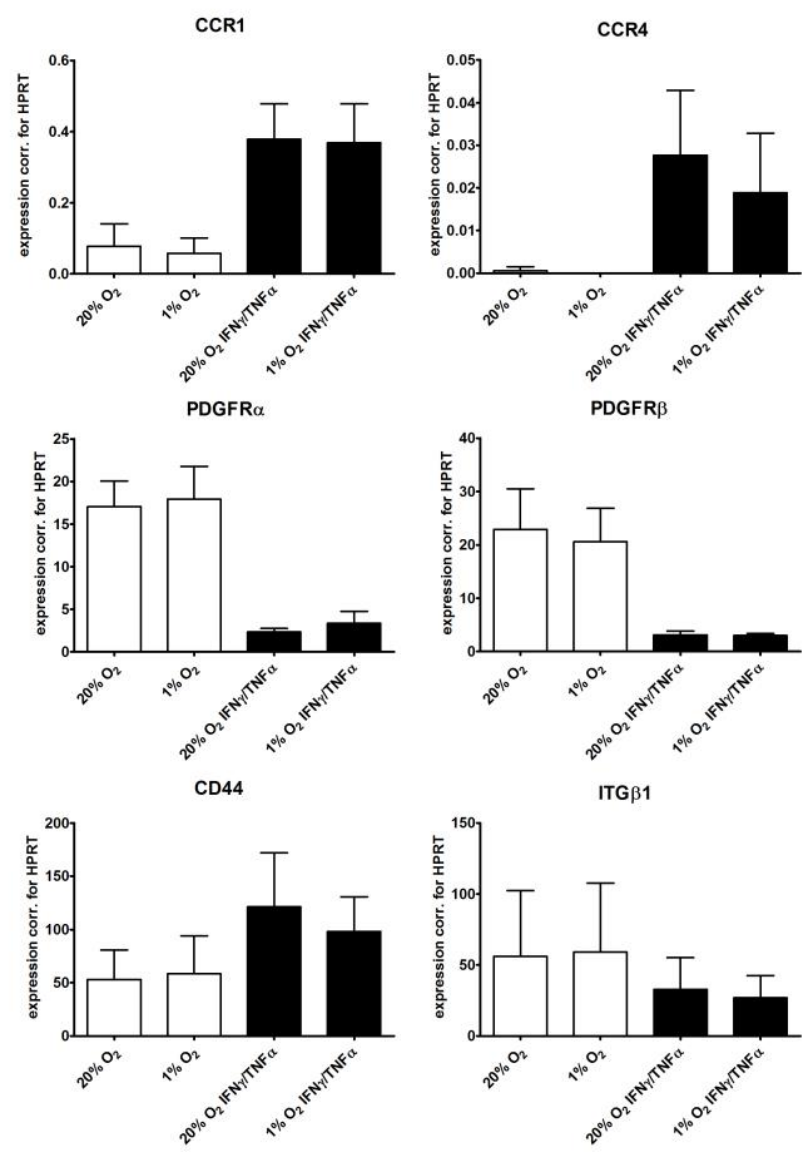

Supplementary figure 1. MSC culture under hypoxia and the effect on expression of migration and adhesion receptors. MSCs ( $\mathrm{N}=3$ donors with triplicate samples for each donor) were cultured for $48 \mathrm{~h}$ under $20 \%$ of oxygen (normoxic) or $1 \%$ of oxygen (hypoxic) conditions with additional $24 \mathrm{~h}$ culturing in combination with or without $50 \mathrm{ng} / \mathrm{ml}$ of IFN $\gamma / \mathrm{TNF} \alpha$. Data is shown as mean $\pm \mathrm{SD}$. 

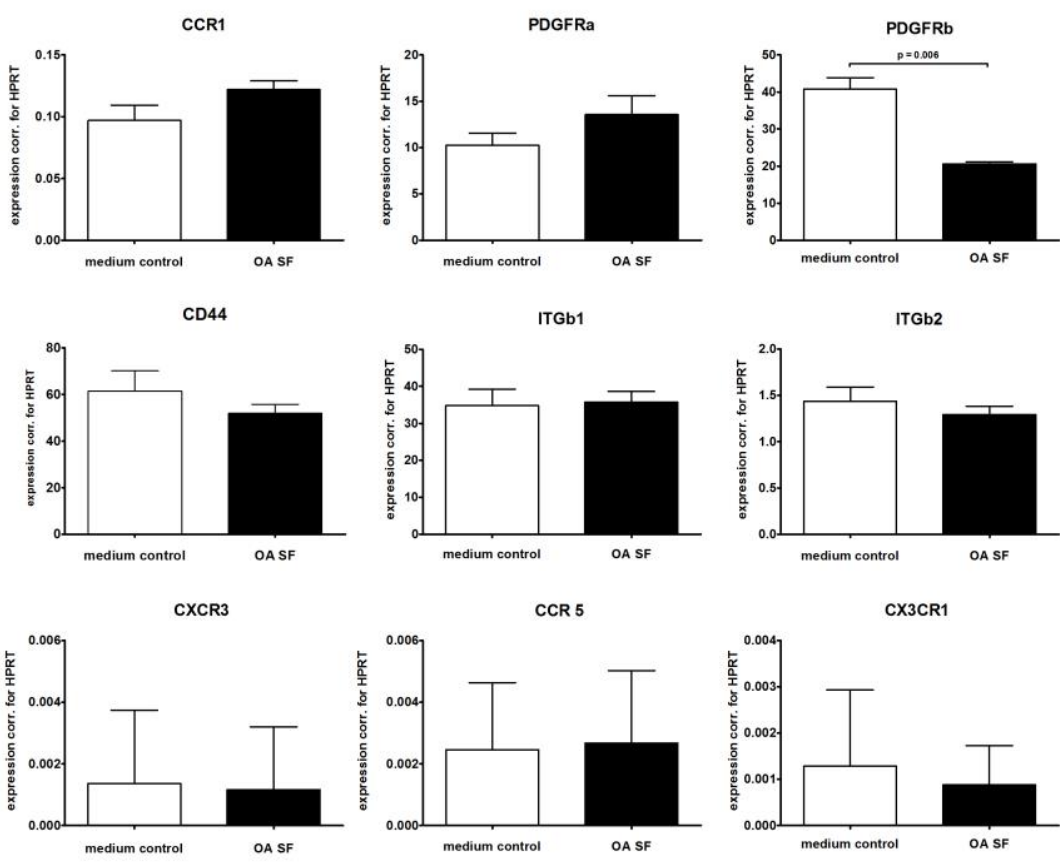

Supplementary figure 2. MSC culture with OA SF and the effect on expression of migration and adhesion receptors. MSCs ( $\mathrm{N}=3$ donors) were cultured for $48 \mathrm{~h}$ with $20 \%$ OA SF in serum free medium. Data shown as mean $\pm \mathrm{SD}$. 

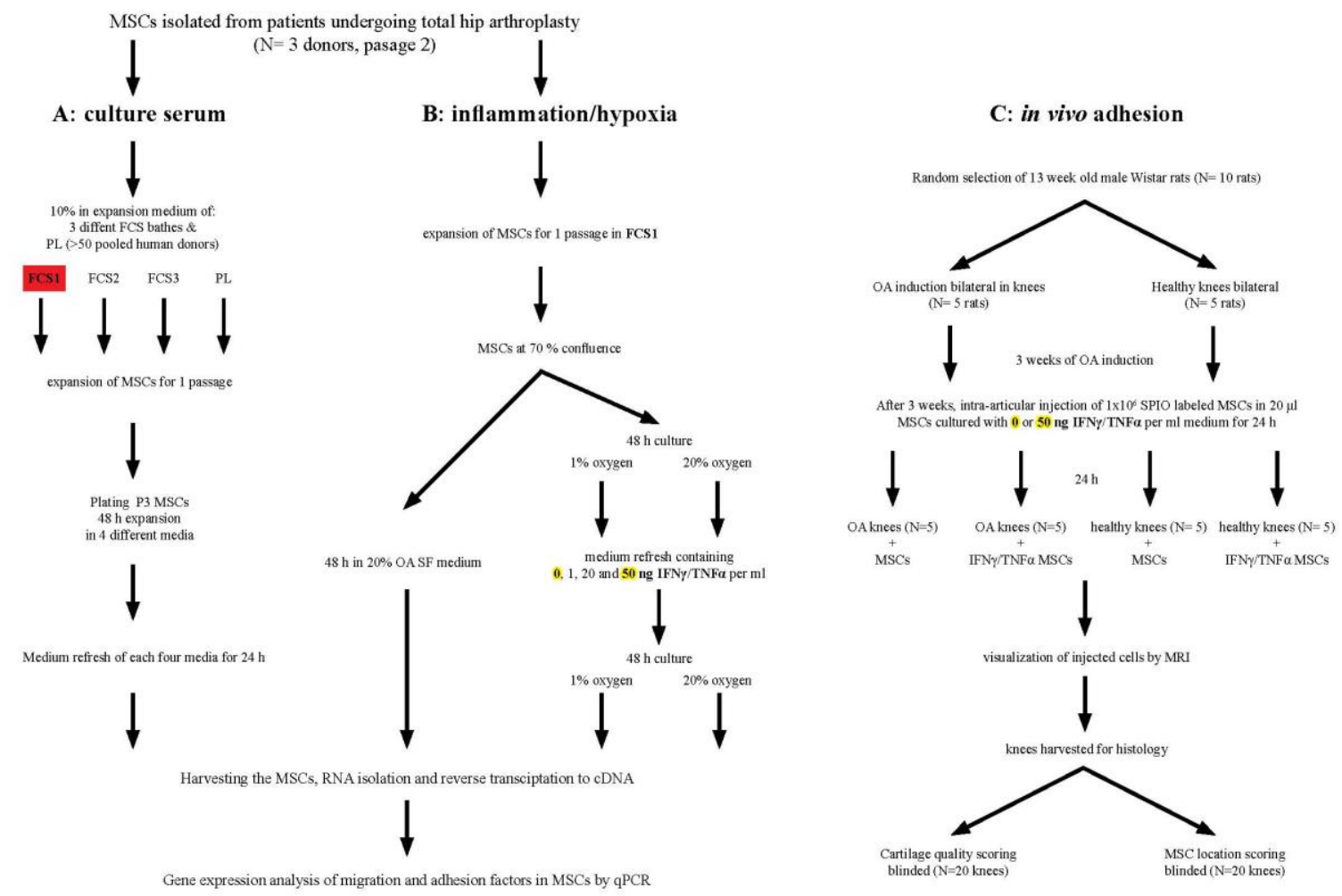

\section{Supplementary figure 3.}




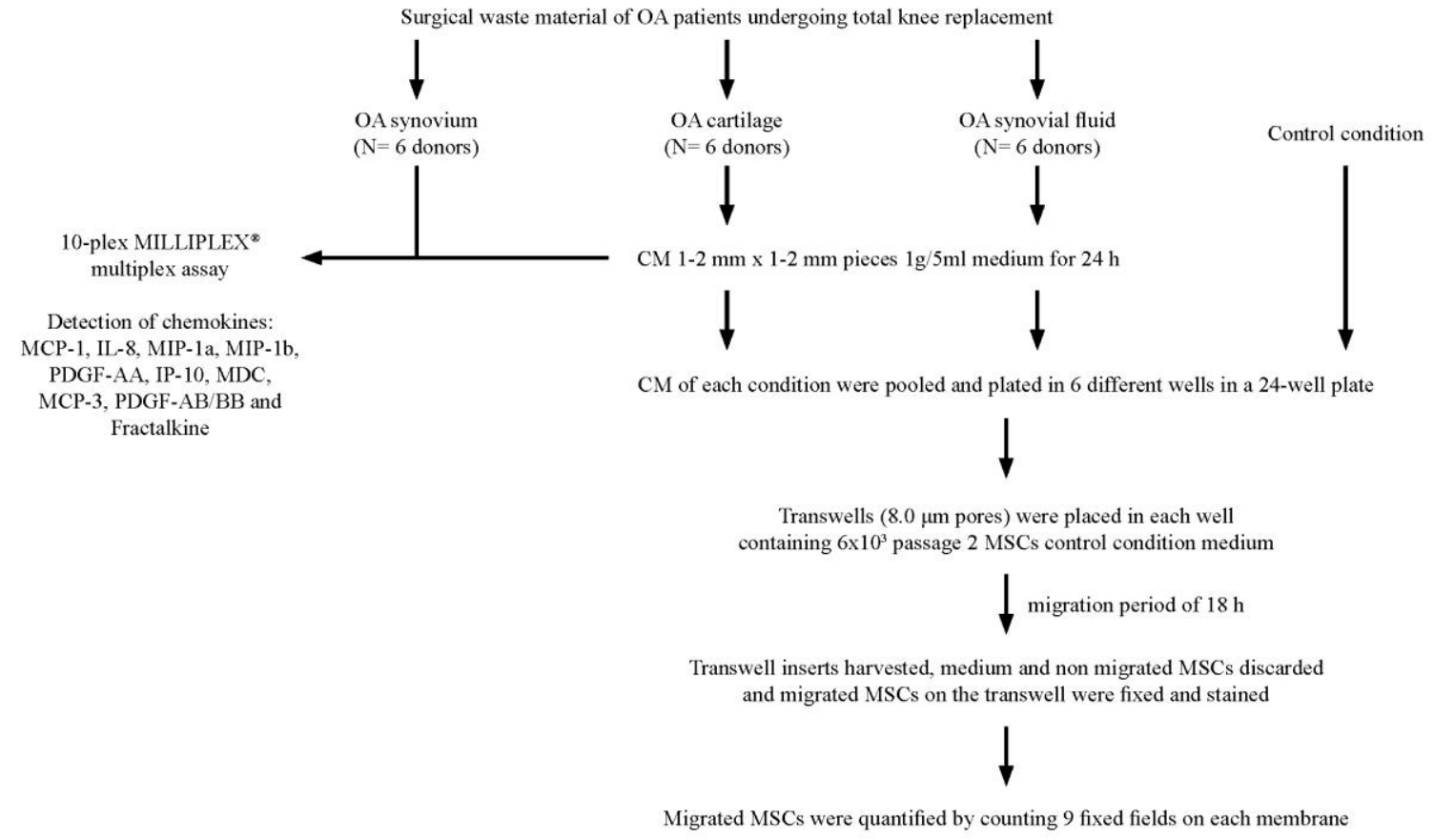

Supplementary figure 4. 